\title{
AN ANALYSIS ON CALP IN REPORT TEXT FOR SECOND GRADE SENIOR HIGH SCHOOL
}

\author{
Muryanti ${ }^{1}$, Mahdum $^{2}$, M. Nababan ${ }^{3}$ \\ Faculty of Teachers Training and Education, Riau University, Riau, Indonesia \\ ${ }^{1}$ muryanti12@gmail.com, Tel. +6285264578294 \\ 2mahdum1211@gmail.com, Tel. +62811752573 \\ ${ }^{3}$ Tel. +6285278371860
}

\begin{abstract}
This study was about the existence of CALP (academic words) in report text for second grade senior high school. The aim of this study was to find out 1) the percentage and 2) the frequency of academic words (CALP words) contained in report text used for second grade senior high school. Six report texts from three different publishers were chosen through purposive sampling. The analysis was based on the Academic Word List (AWL) which comprises of 10 level of frequency, from the highest (level 1) to the lowest (level 10). It was found that there were 33 academic words in the six report texts, and 12 of them or $36.37 \%$ belong to level 1 . It implies that most academic words contained in the texts belong to the highest frequency level. Based on the result, it is recommended for teachers to concern more on material selection to fulfill students' need in academic words.
\end{abstract}

\section{Keywords:}

CALP, Academic Words, Report Text

\section{Academic Discipline}

Education

\section{SUBJECT CLASSIFICATION}

English Subject Classification

\section{TYPE (METHOD/APPROACH)}

\section{Descriptive Research}

\section{INTRODUCTION}

Based on the curriculum of 2006, senior high school students are intended to learn the English four language skills: listening, reading, speaking and writing. The curriculum includes the comprehension of 13 kinds of literary texts. Second grade senior high school students are taught around four kinds of the genres, which are narrative, spoof, hortatory exposition, and report. These kinds of text are expected to help students in achieving desired language proficiency.

When talking about language proficiency, Cummins (1979) in volume number 2 edited by Street and Hornerberg (2008) distinguishes language mastery into two levels of proficiency. The first level of proficiency is known as BICS (Basic Interpersonal Communication Skill). It is a terminology used to classify learners' ability in using language in daily conversation without cognitive process. For example, students' daily conversation about someone's favorite celebrity, someone's daily activity, etc is considered as BICS. Therefore, learners can be considered proficient in BICS if they can talk fluently in that language.

Whereas, the second level, CALP (Cognitive Academic Language Proficiency) is used to classify learners' ability in writing, speaking, listening, and reading academic works with cognitive processes, such as synthesizing, analyzing, and evaluating.

Students need to learn both BICS and CALP since they need both of them in order to be successful language learners. However, what happens in reality is that most people are not really concerned about CALP. Nevertheless, CALP is really needed for English students to be able to read and write academic works, such as writing an essay, business letter, read a report text, or others successfully (Scarcella, 2003).

However, Lawrence, White, and Snow (2010) have found that English students tend to struggle to comprehend academic text because they lack of academic words and lack of exposure to the language. Moreover, Roengpitya (2010) highlights that most EFL students are lack of exposure to academic language because all subjects other than English subject is taught in students' native language. Therefore, it will be hard for students to attain academic language. These statements are also supported by Kramsch (2000) who says that academic language is not everyday language hence it needs to be conducted with academic discourse. These findings imply that in teaching academic text, there should be a vocabulary selection. The selection is supposed to prioritize the low frequent vocabularies since students will need these words for their academic activities.

Cummins (1984) through his research over 400 teachers' referral form and assessment conducted on students in Canadian school system found that most teachers considered that children had mastered English if they were able to 


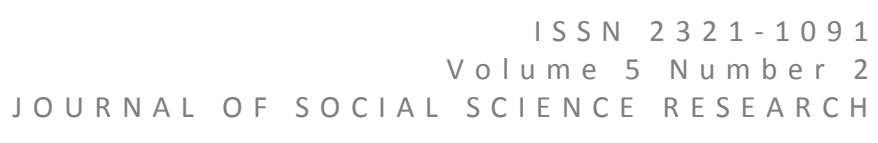

make conversation in this language. While in fact, they didn't get good score in academic tasks. It then shows that there was a misunderstanding over the BICS and CALP of the students, or ignorance of the latter.

It also happens in most EFL classrooms that the students tend to face difficulties in doing academic reading and writing. For example, they greet their teachers or introduce themselves properly, but they have difficulty in using correct salutations when writing a business letters or when reading articles about science, etc.

In addition, most teachers tend to wrongly think that students have mastered English if they are able to make English conversation. Yet, the question as to why those students who are able to speak in English cannot get high score in academic writing remains unanswered. This problem is actually due to misunderstanding of BICS and CALP. If a student is able to speak or converse in English, it could mean that he has proficient in BICS (Basic Interpersonal Communication Skill). We cannot generalize it as one being proficient in English. This is because language proficiency has to include two aspects, BICS and CALP. However, many teachers and even lecturers don't realize the existence of CALP.

For students itself, they tend to be unable to identify academic words and non-academic words in the text. This poor knowledge can affect students' ability in mastering CALP because academic words are the core of CALP. People will not be proficient in CALP if they cannot identify academic words.

The reason for this problem might be that because the textbooks, especially the texts within, do not contain enough CALP words. As second grade senior high school students, they should learn four types of text. Two of them, report and hortatory exposition, are kind of factual text. They should contain technical terms and be relating to real life (Bently, 2008). In other words, those texts should contain academic words. Since report text is the first factual text taught at second grade, writer prioritizes it as the subject of the study. This writing is supposed to make a study on this so that we can make sure that the texts have already provided academic words. Therefore, this study is to know (1) percentage of CALP words in the report text for second grade senior high school and (2) the level of academic words used in report text for second grade senior high school.

\section{RESEARCH METHODOLOGY}

The research was conducted on 31 January - 5 February 2014. It took place in Pekanbaru. This study is a descriptive research. This type of research is used to describe and interpret the data being studied. The aim of this research is to identify the CALP in the report text for second grade senior high school. According to Williams (2007), descriptive research is research design used to examine the situation involving identification of attributes of a particular phenomenon based on an observational basis. Therefore, the writer uses this research design in conducting this study.

The subject in this research is all report texts in textbooks which are mostly used for second grade senior high school. Three textbooks from different publishers are used in senior high school, they are Look Ahead from Erlangga, Developing English Competencies, and Interlanguage from Education Ministry (bse books).

The data taken in this research is in the form of words. The words are the academic words contained in the report text for second grade senior high school. In collecting such data, this research uses Academic Word List (AWL) as instrument. AWL contains list of academic words classified in 10 levels. Level 1 is the highest frequency academic words and level 10 is the lowest one. This list is developed by Averil Coxhead (2000).

To collect the data for this research, a purposive sampling is used. It contains a set of report text that is taken from several textbooks. Then, the sample will be examined in order to find the academic words contained for the further analysis. In this process, the writer will be assisted with AWL (Academic Word List) Highlighter developed by Averil Coxhead, University of Nottingham, to identify the data.

In analyzing the data, the writer will use content analysis which consists of six steps (Gall, 2005):

1. Preparing the database

After the samples are collected through sampling process, they are ready to be analyzed. The analysis process will be assisted with Academic Word List (AWL) Highlighter. In this process, the data gained are in the form of words (academic words) which will be highlighted by the software.

2. Sequencing the data

After the highlighted words are identified, they will be sequenced based on the frequency level. According to Coxhead (2000), the frequency is divided into 10 levels (Appendix 1). Level 1 is for the highest frequent words, while the level 10 is for the lowest ones.

3. Grouping the data into categories

The sequenced data will be grouped into categories. Even though the highlighted data have been sequenced systematically, it still needs to be grouped in order to clearly distinguish it from other levels. Moreover, it is also helpful for calculating the data which share the same category. Therefore, the data will be group based on its level.

4. Coding each data

The coding process still relates to the frequency level of the academic words found. Each word will be coded based on the categories they are in. for example, the words that share the category of level 1 will be labeled as 1 , and so on. 
5. Cumulating all the coded data

The coded data, then, will be cumulated. Through this step, we will be able to identify how many academic words occur in the sample in general. Also, it will help us to identify the number of academic words in particular level occur in each text sample. To support the cumulating, the data will be presented in percentage. According to Hatch and Farhady (1982: 46), to obtain the percentage, we can divide the $F$ of the level that we want to check by the sum of frequencies $(\mathrm{N})$ and multiply by $100 \%$. It is formulated as follow:

$$
\mathrm{P}=\frac{F}{N} \times 100 \%
$$

In this study, $\mathrm{F}$ is the number of academic words in particular level that we want to count, and $\mathrm{N}$ is the total number of academic words that are obtained.

6. Generating construct that emerge from the categories

All the data obtained can give a meaningful meaning towards the study. Therefore, through the previous five steps, we can construct the next step, which is the outlook of academic words existence in the report text used for second grade senior high school.

\section{FINDINGS AND DISCUSSION}

Two report texts of each textbook were taken as the sample. The sample is taken based on the appropriateness to the 'standard of competence' and the 'basic competence' of curriculum 2006. These report texts were then examined with assistance of AWL Highlighter. The result of the check was in the form of words categorized on particular level. Therefore, the result will be explained in the basis of two kinds of classification: the level and the part of speech.

\section{Academic Words Based on Level}

According to Coxhead (2000), academic words are classified into ten levels. The range is from the highest frequent (level 1) to the lowest one (level 10). In the report texts which have been examined, there are 33 academic words found. Each academic word found belongs to different level. They are in level 1, level 2, level 3, level 4, level 5, level 7 , level 9, and level 10. None of them belongs to level 6 and 8. The total number of words is as $\mathrm{N}$ and the words in certain level is as F. If we count the percentage of words in each level using the percentage formula we can see the result as follow.

Table 1. Level of Academic Words

\begin{tabular}{ccc}
\hline $\begin{array}{c}\text { Level of Academic } \\
\text { Words }\end{array}$ & Number & Percentage \\
& & \\
1 & 12 & $36.37 \%$ \\
2 & 5 & $15.15 \%$ \\
3 & 3 & $9.09 \%$ \\
4 & 2 & $6.06 \%$ \\
5 & 6 & $18.18 \%$ \\
7 & 3 & $9.09 \%$ \\
9 & 1 & $3.03 \%$ \\
10 & 1 & $3.03 \%$ \\
& & \\
\hline Total & 33 & $100 \%$ \\
\hline
\end{tabular}

From the table above, it can be seen that from all the academic words used, those in level 1 are the most used in the text, while words in level 9 and 10 are the least used. The numbers of words are $36.37 \%(12)$ in level $1,15.15 \%(5)$ in level 2, 9.09\% (3) in level 3, 6.06\% (2) in level 4, 18.18\% (6) in level 5, 9.09\% (3) in level 7, 3.03\% (1) in level 9, and also $3.03 \%(1)$ in level 10 .

\section{The Distribution of Academic Words}

The distribution of the academic words found is not equal among the text. One text might have more academic words than do the others. Besides, one text might also have words from certain level while others not. For instance, one text might have word from level 9 , while other texts do not have it. The distribution of academic words in six examined 
texts can be seen in table 4.10 below. The percentage is gained by dividing the number of words in each text $(F)$ with total words $(\mathrm{N})$.

Table 2. Distribution of Academic Words

\begin{tabular}{ccc}
\hline Text & Number & Percentage \\
\hline 1 & 15 & $45.46 \%$ \\
2 & 5 & $15.15 \%$ \\
3 & 5 & $15.15 \%$ \\
4 & 4 & $12.12 \%$ \\
5 & 2 & $6.06 \%$ \\
6 & 2 & $6.06 \%$ \\
\hline Total & 33 & $100 \%$ \\
\hline
\end{tabular}

From the table above, it can be seen that the $1^{\text {st }}$ text has contributed most academic words finding. From total 33 words found, it contributes 15 words or equivalent $45.46 \%$. The $2^{\text {nd }}$ and the $3^{\text {rd }}$ text contribute equal number of words, which are 5 words or equivalent $15.15 \%$ of each. The $4^{\text {th }}$ text contributes 4 words or equivalent $12.12 \%$. The last two texts have the least number of found academic words, which are 2 words or equivalent $6.06 \%$ of each.

\section{Academic Words Based on Part of Speech}

According to Eckersley \& Eckersley (1980), words can be classified into eight categories. They are noun, verb, adverb, adjective, pronoun, preposition, conjunction, and interjection. The former four can be classified as content words, while the latter as empty word. In this case, academic words appear as content words, whether as verb, noun, adverb, or adjective. The academics words found can be grouped in those classifications as seen in table 4.23 below. The percentage is obtained by using percentage formula. In this case, the number of academic words in certain part of speech is as $\mathrm{F}$ and the total number of academic words found in the whole texts is as $\mathrm{N}$.

Table 3. Academic Words Classification Based on Part of Speech

\begin{tabular}{ccc}
\hline Part of Speech & Number & Percentage \\
\hline Verb & 6 & $18.18 \%$ \\
Noun & 15 & $45.46 \%$ \\
Adjective & 9 & $27.27 \%$ \\
Adverb & 3 & $9.09 \%$ \\
\hline Total & 33 & $100 \%$ \\
\hline
\end{tabular}

From the table above, it can be seen that the most frequently used words belong to noun part of speech (15 out of 33 or equivalent $45.46 \%$ ). It is followed by the number of words in adjective part of speech with 9 out of 33 or $27.27 \%$. The third frequently used is the words which belong to verb part of speech, with 6 out of 33 words or equivalent $18.18 \%$. The least frequently used is the words which belong to adverb part of speech, with 3 out of 33 words or equivalent $9.09 \%$.

\section{Discussion on Research Findings}

Text is an essential medium to introduce words to language learners, as they can see it directly with the usage of the words in a sentence. Basically, text contains various words, both academic and non academic words. Therefore, students can learn academic and non academic words at the same time.

According to West (cited in DehGaedi, 2013), there should be at least one unknown word in every fifty words. It refers that in a text, academic words might appear less frequent than non academic words. It is because the academic word is a word that has more specific use, meaning, and difficulty. That's why it should not appear in tremendous number in a text used for high school students. If academic words appear in huge number in one short text, students will get difficulty in understanding the text and the meaning of the academic words. Even though the portion of academic words in a text may be less than non academic words, it is still very important in order to introduce them through such way.

As stated by Roessingh (2006), students with GE 5 are expected to acquire 10,000 -12,000 words including $3,000-5,000$ high frequency academic words. In this case, the examined texts have shown the availability of academic words, even the lowest frequent ones. Based on the result, we can see that the high frequency words appear more frequent than the lowest ones. It can be related to the target reader of the text, whom is high school students.

In addition to the number of academic words found in the six texts, we can refer to West's (cited in DehGaedi, 2013) statement saying that there should be at least one unknown word (it refers to academic word) in every fifty words 
for the adequate comprehension of a text. In each of the text, it has already fulfilled this criterion on which it contains enough CALP words. For example, in the first text containing 207 words, 15 of them are academic words (even though it needs only around four words). Another example is that the last text containing 142 words contains 2 academic words.

\section{CONCLUSION AND RECOMMENDATION}

\section{Conclusion}

After conducting research entitled "An Analysis on CALP in report text for Second Grade Senior High School", some conclusions can be drawn as follows:

1. Based on level classification, most academic words found belong to the highest frequency level of academic words or level 1 (12 words out of 33 or equivalent $36.37 \%$ ).

2. Based on part of speech classification, all academic words found belong to content words and most of them belong to noun ( 15 out of 33 or equivalent $45.46 \%$ ).

Therefore, we can see that the academic words are available in report text used for second grade senior high school and still acceptable for the level of the students.

\section{Recommendations}

Based on the research finding, it is clear that it only refers to single type of text. Meanwhile, students do not only learn this type of text at school. They are also provided various types of text to be learned. Even though this research finding shows the existence of CALP in the report texts contained in the students' textbooks, writer cannot draw a generalization towards whole learning materials. Therefore, writer would like to recommend other researchers to conduct such research upon other types of text used for second grade senior high school students. Besides, the writer also would like to recommend teachers to concern more about material selection so that it would fulfill the need of the students.

The applications of these recommendations are expected to help researcher, teacher and also students to draw a holistic picture of academic language or CALP.

\section{ACKNOWLEDEMENTS}

This research wouldn't be possible without contribution of various people. Therefore, I would like to express my very great appreciation to Dr. Mahdum, M.Pd as my first consultant and Drs. M. Nababan, M. Hum as my second consultant, for their valuable and constructive suggestion during the planning and development of this research, and their advice and assistance in keeping my progress on schedule. Their willingness to give their time so generously has been very much appreciated.

\section{REFERENCES}

[1] Achmad Dedi, Achmad Sugeng, and Effendi. 2008. Developing English Competencies 2: for Grade XI Senior High School (SMA/MA). Pusat Perbukuan Depdiknas. Jakarta.

[2] Bently, K. 2008 . Genres of Writing. Highland Literacy Project. UK.

[3] Coxhead, A. 2000. A New Academic Word List. TESOL Quarterly. 34: 213-238.

[4] Cummins, J. 1984. Bilingual and Special Education: Issues in Assessment and Pedagogy. Multilingual Matters. Clevedon, England.

[5] DehGhaedi, M. 2013. Lexical Analysis of General English Textbook in Iranian Universities. Vol. 4 (2). IJLLALW. Iran.

[6] Eckersley, C.E, and Eckersley, J.M. 1980. A Comprehensive English Grammar: for Foreign Students. Longman Commonwealth Printing Press Ltd. Hong Kong.

[7] Gall, J.P. a.o. 2005. Applying Educational Research: A Practical Guide. Fifth ed. Pearson. USA.

[8] Hatch, E. M. and Farhady, H. 1982. Research Design and Statistics for Applied Linguistics. Newbury House. New York.

[9] Joko Priyana, Riandi, and Anita Prasetyo Mumpuni. 2008. Interlanguage: English for Senior High School Students XI Science and Social Study Programme. Pusat Perbukuan Depdiknas. Jakarta.

[10] Kramsch, C. 2000. Statement on Teaching Philosophy. University of California. Berkeley.

[11] Lawrence, J.F., White, C., and Snow, C. E. 2010. The Words Students Need. ASDC. United States.

[12] Roengpitya, R. 2010. Can Reading Selections Positively Influence Reading Thinking, and Writing Skills? A Paper. Mahidol University. Thailand.

[13] Roessingh, H. 2006. BICS-CALP: An Introduction for Some, a Review for Others. Journal. TESL Canada Journal 23 (2). Canada.

[14] Scarcella, R. 2003. Academic English: A conceptual Framework. Linguistic Minority Research Institute Newsletter. University of California. Santa Barbara. 
[15] Street, B. and Hornerberg, N.H. 2008. BICS and CALP: Empirical and Theoretical Status of the Distinction By J. Cummins. Encyclopedia of Language and Education, $2^{\text {nd }}$ Edition Volume 2: 71-83. Springer Science + Business Media LLC. New York.

[16] Sudarwati, Th. M. and Eudia Grace. 2007. Look Ahead 2: An English Course for Senior High School Students Year XI. Penerbit Erlangga. Jakarta.

[17] University of Nottingham. $\quad$ n.d. AWL $\quad$ Highlighter. $\quad$ Retrieved from http://www.nottingham.ac.uk/alzsh3/acvocab/awlhighlighter.htm

[18] Williams, C. 2007. Research Methods. Journal of Business \& Economic Research, Vol 5 No 3. Grand Canyon University. 